\title{
積層複合材の板厚方向の衝撃圧縮特性
}

横 山

隆*

\section{Through-Thickness Compressive Characteristics of Laminated Composites at High Rates of Strain}

by

\author{
Takashi YокоуамА *
}

\begin{abstract}
Through-thickness compressive characteristics of laminated composites at high rates of strain are evaluated using the standard split Hopkinson pressure bar. Three types of laminated composites, namely symmetric cross-ply carbon/epoxy, plain-woven carbon/epoxy and plain-woven E-glass/epoxy with almost the same thickness are tested at room temperature. Cylindrical compression specimens are machined such that the longitudinal direction of each specimen is parallel to the thickness direction of the laminates. The effects of strain rate, type of reinforcing fiber and prepreg form on the secant modulus, ultimate compressive strength, ultimate compressive strain and absorbed energy are examined in detail. It is shown that the cross-ply carbon/epoxy laminated composite exhibits the highest strength characteristics at low and high rates of strain, and there is no correlation between the absorbed energies and the Charpy impact energies for the laminated composites tested.
\end{abstract}

Key words : Absorbed energy, CFRP, Charpy test, GFRP, Hokinson bar, Impact loading, Laminated composites, Secant modulus, Strain rate, Ultimate compressive strength, Ultimate compressive strain

\section{1 緒言}

複合材料は金属材料と比較して比強度, 比剛性が高い ため近年, 航空機, 自動車, スポーツ用具等の分野で広 範に使用されている。積層された複合材料（以下積層複 合材）の静的強度特性を決定する種々の試験法について は，すでに $\mathrm{ASTM}^{1)}$ や JIS $\mathrm{S}^{2)} に$ おいて標準化されている。 また線形破壊力学に基づくモード I，IIにおける静的層 間破壞じん性を決定する試験法も規格化 ${ }^{2)}$ されている. しかし衝撃荷重下に打ける変形強度や層間破壊じん性を 決定する試験法については，まだ標準化されるに至って いない. 積層複合材の衝撃特性データは複合材料構造 物の安全設計上不可欠であるため, 積層面内における圧

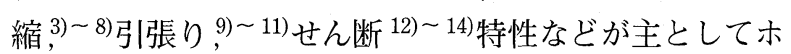
プキンソン棒法により測定されてきた. 板厚方向の圧縮 特性については少数 $\left.{ }^{15)}, 16\right)$ を除いては, あまり研究され ていないが，積層複合材の衝撃貫通特性と衝撃圧縮特性 との相関性を評価する際には重要となる。

本報告の目的は, 積層複合材の板厚方向の衝撃圧縮応 カーひずみ特性を評価することである，まず，標準的な 圧縮型ホプキンソン棒装置 ${ }^{17)}$ を用いて, プリプレグ形態 と強化繊維の異なる 3 種類の積層複合材から板厚方向に 切出した薄い円柱状試験片について, 高ひずみ速度 $(\dot{\varepsilon} \fallingdotseq$ 1000/s オーダ）での破壞までの圧縮応力ーひずみ関係を 測定した。この圧縮応力ーひずみ関係から, 割線係数, 極限圧縮強度, 極限圧縮ひずみ, 極限圧縮ひずみ値まで の吸収エネルギを決定した。次に，インストロン試験機 により低・中ひずみ速度での圧縮応力ーひずみ関係を測
定した。両試験結果の比較に基づき, 積層複合材の圧縮 特性に及ぼすひずみ速度, プリプレグ形態, 強化瀻維材 の影響を詳細に調べた。さらに, シャルピー衝撃試駼機 により切欠きのない短冊状積層複合材のフラットワイズ （板面と垂直）方向の曲げ吸収エネルギの測定を試み, 衝 撃圧縮荷重下での板厚方向の吸収エネルギとの相関関係 を考察した。

\section{2 積層複合材の引張特性と圧縮試験片の形状寸法}

供試材として 3 種類のほぼ同一の厚さ $(h=3.80$ $3.96 \mathrm{~mm}$ ) をもつ直交積層 $\mathrm{CFRP}$ 材, 平織り CFRP 材, 平 織り GFRP 材（サカイ・コンポジット(株）を使用した。 それぞれの積層複合材のプリプレグ形態，板厚 $h$ ，プライ 数を, Table I に示す.ささらに積層複合材の強化繊維材打 よびマトリックス樹脂の種類, 繊維含有率を, Table IIに 示す.これらよりその板厚方向に, Fig. 1に示すような 円柱（板）状圧縮試験片（直径 $8 \mathrm{~mm}$ ）を機械加工によ り採取した。 円柱の直径寸法 $d$ の決定は，等方均質材の 衝撃圧縮試験片における最適な細長比 $(h / d \fallingdotseq \sqrt{3} / 4)$ の

Table I. Specifications of three different laminated composites.

\begin{tabular}{l|c|c|c}
\hline \multicolumn{2}{l|}{} & Prepreg & Thickness $h$ (No. of ply) \\
\hline $\begin{array}{l}\text { Carbon/ } \\
\text { epoxy }\end{array}$ & $\mathrm{A}$ & $\begin{array}{c}\text { Unidirectional } \\
{\left[0^{\circ} / 90^{\circ} / 0^{\circ} / 90^{\circ} / 0^{\circ} / 90^{\circ} / 90^{\circ}\right]_{\mathrm{S}}}\end{array}$ & $3.80 \pm 0.04$ (16-plv) \\
\cline { 2 - 4 } & $\mathrm{B}$ & Plain-woven fabric & $3.85 \pm 0.04$ (20-plv) \\
\hline $\begin{array}{l}\text { E-glass/ } \\
\text { epoxy }\end{array}$ & $\mathrm{C}$ & Plain-woven fabric & $3.96 \pm 0.02(28$-plv) \\
\hline
\end{tabular}


Table II . Types of reinforcing fibers and resin matrix.

\begin{tabular}{c|c|c|c}
\hline & $\begin{array}{c}\text { Unidirectional } \\
\text { carbon/epoxy }\end{array}$ & $\begin{array}{c}\text { Plain - woven } \\
\text { carbon/epoxy }\end{array}$ & $\begin{array}{c}\text { Plain - woven } \\
\text { E-glass/epoxy }\end{array}$ \\
\hline Fiber & T700S (Torayca) & T300B-3000 (Torayca) & E-Glass \\
\hline Matrix & Epoxy \#2500 $\left(130^{\circ} \mathrm{C}\right)^{*}$ & Epoxy \#2500 $\left(130^{\circ} \mathrm{C}\right)$ & Epoxy \#2500 $\left(130^{\circ} \mathrm{C}\right)$ \\
\hline Fiber volume ratio $V_{\mathrm{f}}$ & 0.67 & 0.60 & 0.45 \\
\hline
\end{tabular}

*Values in parentheses denote the hardening temperature
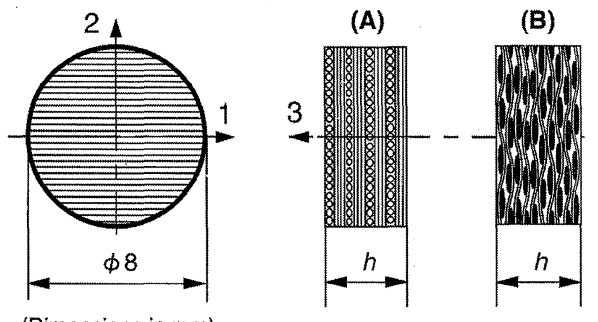

(c)

(Dimensions in $\mathrm{mm}$ )

Fig. 1. Form and dimensions of compression specimens from laminated composites.

理論的検討 ${ }^{18)}$ に基づいている．ホプキンソン棒法による 積層複合材の圧縮試験に打ける最適形状寸法については, Woldesenbet と Vinson ${ }^{7}$ が一方向強化 CFRP 材の面内方 向に採取した $1 / 2 \leqq h / d \leqq 2.0$ の細長比を持つ 7 種類の 異なる円柱状試験片を使用して, 繊維 (1-) 方向 (Fig. 1 参照）とそれと垂直な横 (2-) 方向の極限圧縮強度およ び極限圧縮ひずみに及ぼす細長比の影響を詳細に調べた。 その結果によれば, 繊維 (1-) 方向の圧縮試験では縦割 れを生じるため試験片の細長比の影響を大きく受けるが， 横 (2-) 方向の圧縮試験ではほとんど細長比の影響を受 けない，さらに板厚 (3-) 方向の圧縮強度特性は，横 (2-) 方向とほぼ同じと報告されているので, 本試験にお ける円柱状試験片の細長比を, 等方均質材の場合と同様 $に h / d \fallingdotseq 1 / 2$ と決定した。

基本的機械的特性として，JIS（K7054，K7073）に規 定された形状寸法の引張試験片（幅 $25 \mathrm{~mm}$ ，長さ 250 $\mathrm{mm}$, 厚さ $h / 4)$ を製作して, インストロン試験機によ りクロスヘッド速度 $2 \mathrm{~mm} / \mathrm{min}$ で測定した静的面内引張 り特性値を, Table IIIに示す。一方, 静的層間せん断強度 祗SS は，同様にJIS $(\mathrm{K} 7057, \mathrm{~K} 7078)^{2)} に$ 規定された短い
Table III. Mechanical and physical properties of three different laminated composites.

\begin{tabular}{l|c|c|c}
\hline Property & $\begin{array}{l}\text { Cross-ply } \\
\text { carbon/epoxy }\end{array}$ & $\begin{array}{l}\text { Plain - woven } \\
\text { carbon/epoxy }\end{array}$ & $\begin{array}{c}\text { Plain -woven } \\
\text { E-glass/epoxy }\end{array}$ \\
\hline$E(\mathrm{GPa})$ & 74 & 66 & 33 \\
\hline$\sigma_{\mathrm{B}}(\mathrm{MPa})$ & 1067 & 552 & 399 \\
\hline$\tau_{\text {ILSS }}(\mathrm{MPa})$ & 52 & 60 & 68 \\
\hline$\varepsilon_{\mathrm{F}}(\%)$ & 1.6 & 1.0 & 2.0 \\
\hline$\rho\left(\mathrm{kg} / \mathrm{m}^{3}\right)$ & 1540 & 1470 & 2000 \\
\hline
\end{tabular}

はり試験片（幅 $10 \mathrm{~mm}$, 長さ $30 \mathrm{~mm}$, 板厚 $h$, 支点間距

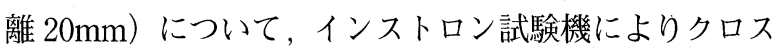
ヘッド速度 $5 \mathrm{~mm} / \mathrm{min}$ での 3 点曲げ試験から決定した。

\section{$3 \cdot 1$ 衝撃圧縮試験}

\section{3 試験方法と試験手順}

試験に使用した圧縮型ホプキンソン棒装置の概略図を， Fig. 2 に示す。本装置は, 直径 $16 \mathrm{~mm}$, 長さ $1500 \mathrm{~mm}$ のホプキンソン棒と呼ばれる入出力棒 (JIS SUJ2 $: E=$ $209 \mathrm{GPa} ， \sigma_{\mathrm{y}}>1200 \mathrm{MPa}$ ) と打出し棒（JIS SK5：直径 $15.9 \mathrm{~mm}$, 長さ $350 \mathrm{~mm}$ ）から構成されている. 打出し棒 の速度測定装置を含む測定系は省略している，以下に試 験手順を簡単に説明する。まず，Fig. 1 に示す円柱状試 験片を入力棒と出力棒の間に挟み込んで取り付ける。試 験片の両端面には摩擦の影響を軽減するために, 潤滑剤 （2 硫化モリブデン）を塗布している，その後，圧力タン ク内に蓄えられた圧縮空気を, 空気作動弁により解放す ることにより打出し棒を発射し, 入力棒の左端面に衝突 させる.このとき, 入力棒の衝突面には緩衝材として電 磁敛板製の円板（厚さ $0.2 \mathrm{~mm}$ ，直径 $16 \mathrm{~mm}$ ）1枚を，前 述の潤滑剤を塗布して貼り付けている。この緩衝材の使 用は，打出し棒による衝撃時に入力棒内に分散性をもつ 入射ひずみパルスが発生するのを極力防止するためであ る。発生した圧縮ひずみパルスは入力棒内を左から右へ 伝ぱし，試験片との界面で機械的インピーダンスの違い からその一部は反射し, 残りは円柱状試験片を通過して 出力棒へ透過する. このとき, 入出力棒上のひずみゲー ジ（共和電業：KSP-2-120-E4）により, 入射, 反射, 透

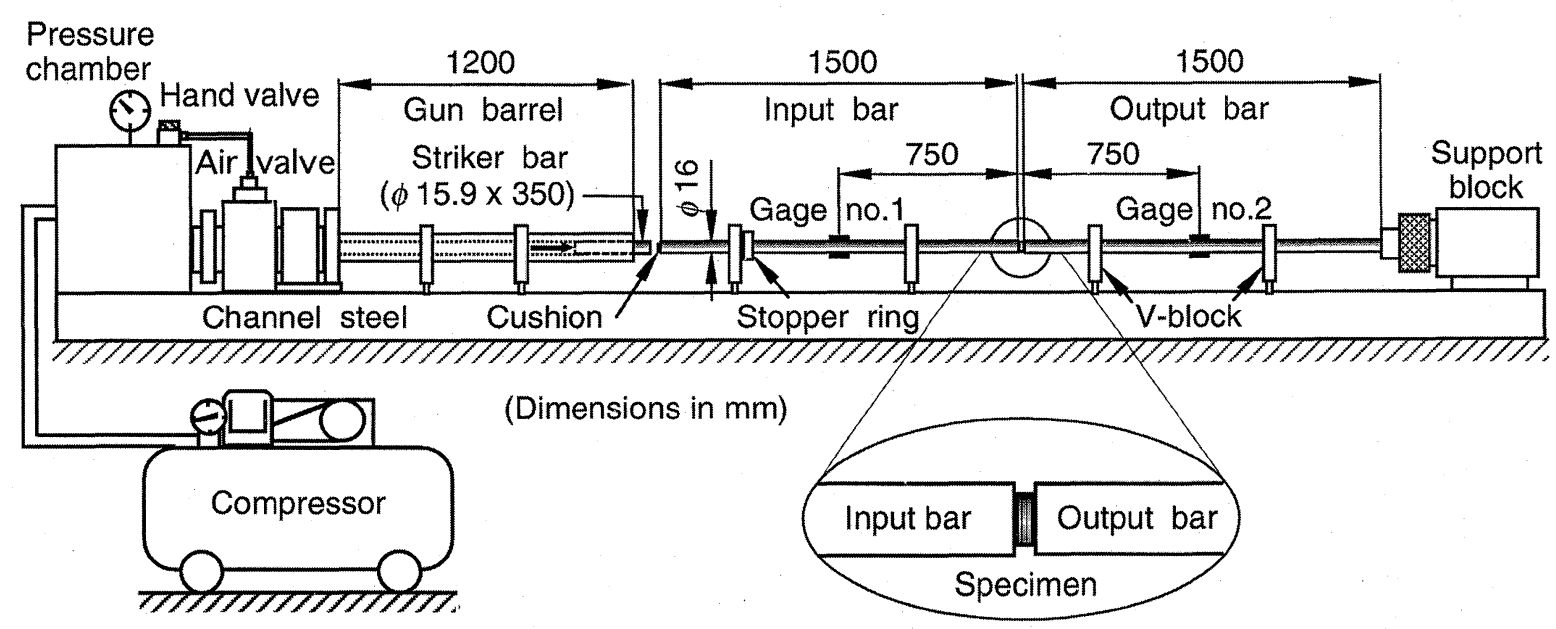

Fig. 2. Schematic diagram of standard split Hopkinson pressure bar (recording system not shown). 
過ひずみパルスを測定しディジタル・ストレージ・オシ ロスコープ (IWATSU：DS-9121) に書込み速度 $1 \mu \mathrm{s} /$ word で記録する.この記録された出力電圧は，データ処 理のためにパーソナル・コンピュータ（NEC：PC-9821 $\mathrm{Xb10)}$ に転送される.

\section{$3 \cdot 2$ ホプキンソン棒法の測定理論}

一次元弾性波伝ぱ理論 ${ }^{19)}$ に基づくと, 円柱状試験片の 圧縮に打ける公称ひずみ $\varepsilon$, 公称ひずみ速度 $\dot{\varepsilon}$, 公称応力 $\sigma$ は，測定された入射，反射，透過ひずみパルス $\left(\varepsilon_{i}\right.$, $\left.\varepsilon_{r}, \varepsilon_{t}\right)$ により，それぞれ次式で与えられる.

$$
\begin{aligned}
& \varepsilon(t)=\frac{2 c_{0}}{h} \int_{0}^{t}\left\{\varepsilon_{i}\left(t^{\prime}\right)-\varepsilon_{t}\left(t^{\prime}\right)\right\} d t^{\prime} \\
& \dot{\varepsilon}(t)=\frac{2 c_{0}}{h}\left\{\varepsilon_{i}(t)-\varepsilon(t)\right\} \\
& \sigma(t)=\frac{A E}{A_{s}} \varepsilon_{t}(t)
\end{aligned}
$$

ここで, $A, E, c_{0}$ は 弾性棒の断面積, ヤング率, 縦弾 性波の伝ぱ速度であり， $A_{s}$ は圧縮試験片の断面積である. 式 (1)〜 (3)においては, 試験片の両端面に作用する動的 圧縮応力の釣り合い条件 $\left(\sigma_{1}=\sigma_{2}\right)$ すなわち

$$
\varepsilon_{i}(t)+\varepsilon_{r}(t)=\varepsilon_{t}(t)
$$

が成り立つことを仮定している. 式 (1)〜 (3) から時間 $\mathrm{t}$ を消去することにより，圧縮応力ーひずみ速度一ひずみ 関係が求められる。この圧縮応力ーひずみ関係から，割 接係数 $E_{s}$ (ここでは，原点と $1 \%$ ひずみに対応する応力 を結ぶ直線の勾配として定義），極限圧縮強度 $\sigma_{B}$ ，極限 圧縮ひずみ $\varepsilon_{B}$ （極限圧縮強度に対応するひずみ值．本試 験材料ではこのひずみ值で圧壊を開始しているので破壊 ひずみ $\varepsilon_{F}$ と等しくなる）を決定した，吸収エネルギ $U_{B}$ は極限圧縮ひずみまでの圧縮応力ーひずみ曲線下の面積 から求めた。

\section{$4 \cdot 1$ 静的圧縮試験}

静的圧縮試験はすべてインストロン試験機を使用して， 伸び計を上下アンビル間に取り付けて行なった. Fig. 1 に示す円柱状試験片の形状寸法は，静的圧縮試験片の ASTM 規格 ${ }^{20)}(h / d=1.5 \sim 2)$ を満足していない.この ような細長比の小さい円柱状試験片を使用すると，上下 アンビルと試験片端面間での摩擦拘束による樽型変形の ために，正確な圧縮応力ーひずみ関係が測定できない. 金属板の板厚方向の静的圧縮強度特性の測定では，円板 状試験片を重ねてその圧縮応力ーひずみ特性を測定する 試験の妥当性が，すでに実験的に立証 ${ }^{21) さ れ て い る 。 そ ~}$ こで本試験でも，円板 1 枚のみと円板 2 枚を重ね合わせ た 2 種類の円柱状試験片について，クロスへッド速度 $1 \mathrm{~mm} / \mathrm{min}$ で静的試験を行なって，その圧縮応力ーひず み関係を比較した。一例として, 直交積層 CFRP 材の板 厚方向の圧縮応力ーひずみ関係の比較を, Fig. 3 に示 す。この罒からわかるように，両者の圧縮応力ーひずみ 関係は圧壊 (X印) までほぼ直線関係を示す。板 1 枚 $(h=3.75 \mathrm{~mm})$ の場合には, 圧縮荷重の増大に伴う試験 片両端面での摩擦拘束の影響による樽型変形のため変位

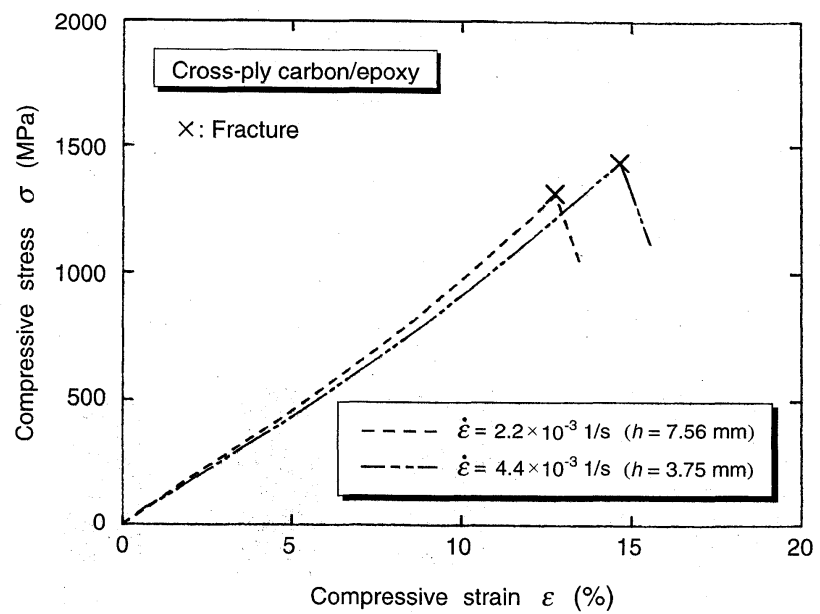

Fig. 3. Comparison of through-thickness compressive stress-strain curves for cross-ply carbon/epoxy laminated composites with two different thicknesses.

が徐々に過大に評価されて，圧縮応力ーひずみ関係の勾 配が円板 2 枚 $(h=7.56 \mathrm{~mm})$ のそれと比較するとやや小さ くなって，極限圧縮ひずみと極限圧縮強度が少し過大に 評価される傾向がみられた。そのため以下では，3 種類 の積層複合板について，すべて円板 2 枚を重ね合せて静 的圧縮試験を実施して，圧壊するまでの圧縮応力ーひず み関係を精密に決定した。

\section{$4 \cdot 2$ 衝撃圧縮試験}

直交積層 CFRP 板（板厚 $h=3.75 \mathrm{~mm}$ ）の円柱状試験 片についての衝撃圧縮試験におけるひずみゲージ出力の代 表的なオシロスコープ記録例を, Fig. 4 に示す.この上 部トレースが入力棒上のひずみゲージ No. 1 からの出力 波形を，下部卜レースが出力棒上のひずみゲージ No. 2 からの出力波形を示している．各トレースの基準時間軸 より下（上）向きの出力が, 圧縮（引張り）ひずみに対 応している。このひずみパルスから試験片の両端面に作 用する圧縮応力履歴をもとめると, Fig. 5 のようになる. この罒より両応力はよく一致していて, 式 (4)の仮定が

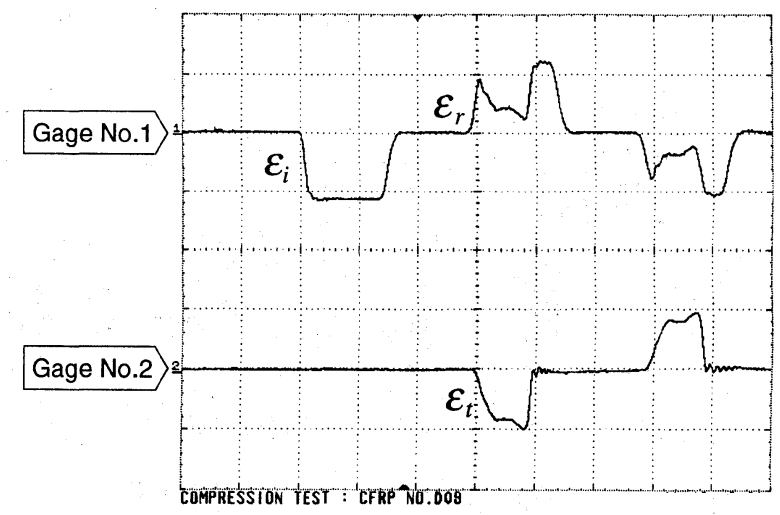

Sweep rate: $100 \mu \mathrm{s} / \mathrm{div}$

Vertical sensitivity

Upper trace: $500 \mathrm{mV} / \mathrm{div}(1209 \mu \varepsilon / \mathrm{div})$

Lower trace: $500 \mathrm{mV} / \mathrm{div}(1167 \mu \varepsilon / \mathrm{div})$

Fig. 4. Oscilloscope records from impact compression test on cross-ply carbon/epoxy laminated composite. 


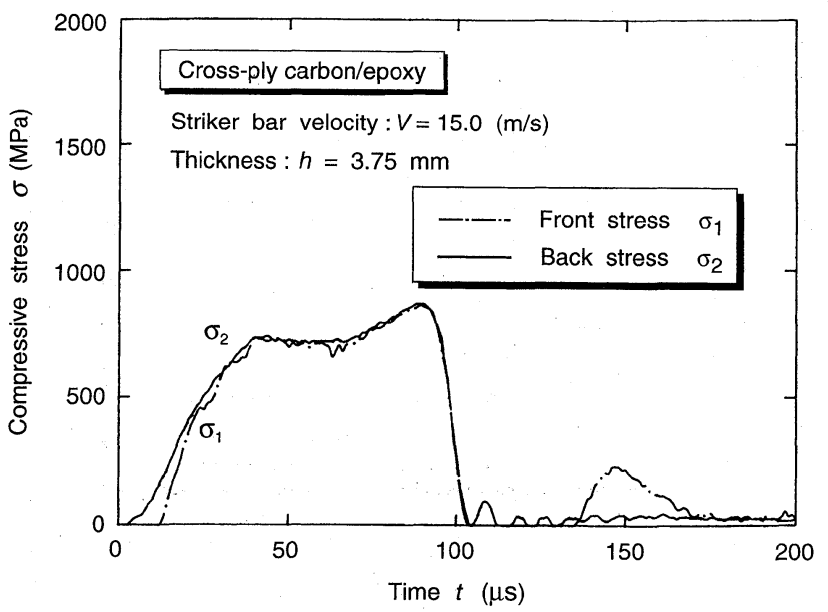

Fig. 5. Axial compressive stress histories measured at front and back faces of compression specimen from cross-ply carbon/epoxy laminated composite.

成立することが証明された。また測定したひずみパルス を式 (1) (3)に代入後, 時間 $t$ を消去して得られる圧縮 応力ーひずみ速度一ひずみ関係を Fig. 6 に示す。この関 係から変形中の試験片内のひずみ速度は一定ではなく, 最大压縮応力 (867MPa) で試験片が圧壊し始めると急激 に変形抵抗が小さくなり，ひずみ速度が $\dot{\varepsilon}=600 / \mathrm{s}$ から政 $=$ $3300 / \mathrm{s}$ まで急速に上昇に転ずることがわかる． $\varepsilon=0$ か ら極限圧縮ひずみ $\varepsilon_{B}(=$ 圧縮破壊ひずみ）に至るまでの ひずみ速度を数值積分し，その值を $\varepsilon_{B}$ で除して平均ひず

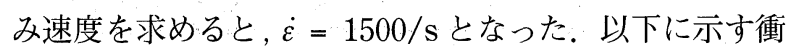
撃压縮応力ーひずみ関係に打いて表示されたひずみ速度 は，全てこのようにして算出した極限圧縮ひずみまでの 平均ひずみ速度を示している。

ひずみ速度が応力ーひずみ関係に及ぼす影響を調べる ために, 直交積層 CFRP 材の静的および衝撃圧縮応力一 ひずみ関係を合せて Fig. 7 に示す。この図に打ける一点 鎖線は, 板厚 $h=7.59 \mathrm{~mm}$ (円板 2 枚)の円柱状試験片をク ロスヘッド速度 $50 \mathrm{~mm} / \mathrm{min}$ で試験した静的圧縮応力ーひ ずみ関係を示す。同様に平織り CFRP 材, 平織り GFRP 材の静的扎よび衝撃圧縮応力ーひずみ関係の比較を，そ れぞれ Fig. 8 と Fig. 9 示す。爷れぞれの衝撃圧縮応力一

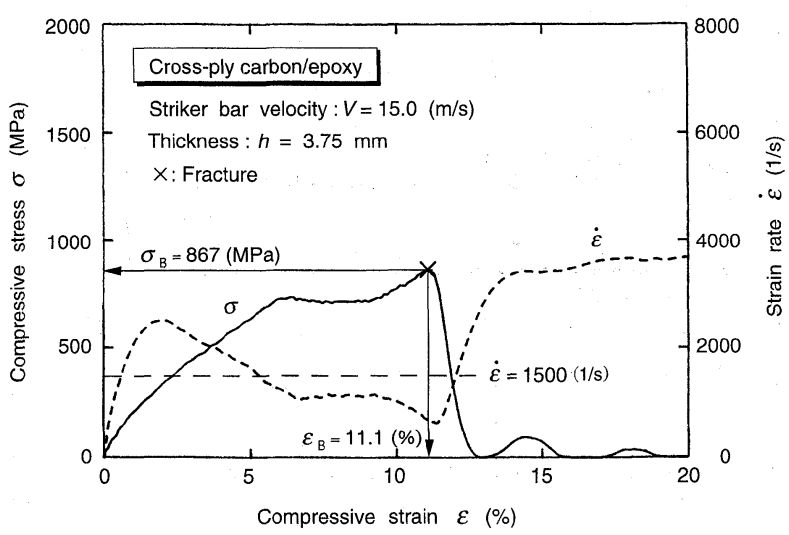

Fig. 6. Through-thickness compressive stress -strain and strain rate-strain relations for cross-ply carbon/epoxy laminated composite.

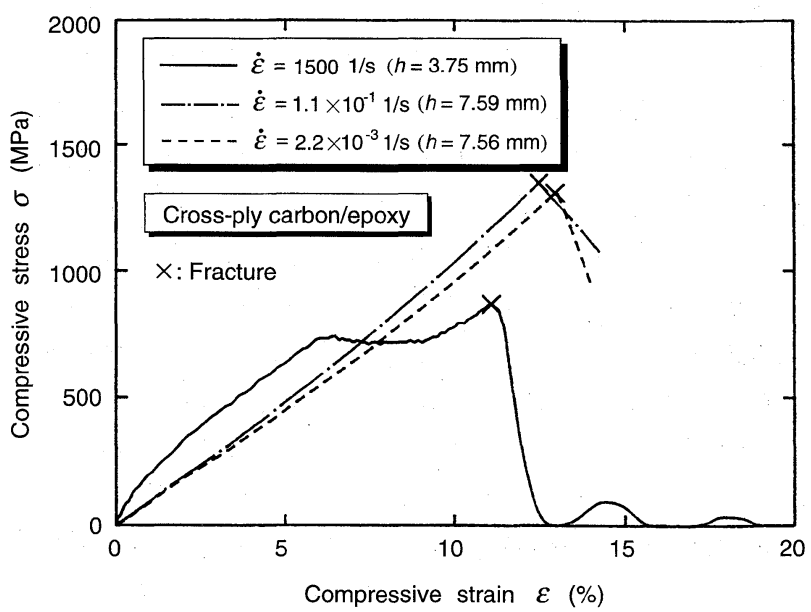

Fig. 7. Through-thickness compressive stress-strain curves for cross-ply carbon/epoxy laminated composite at different strain rates.

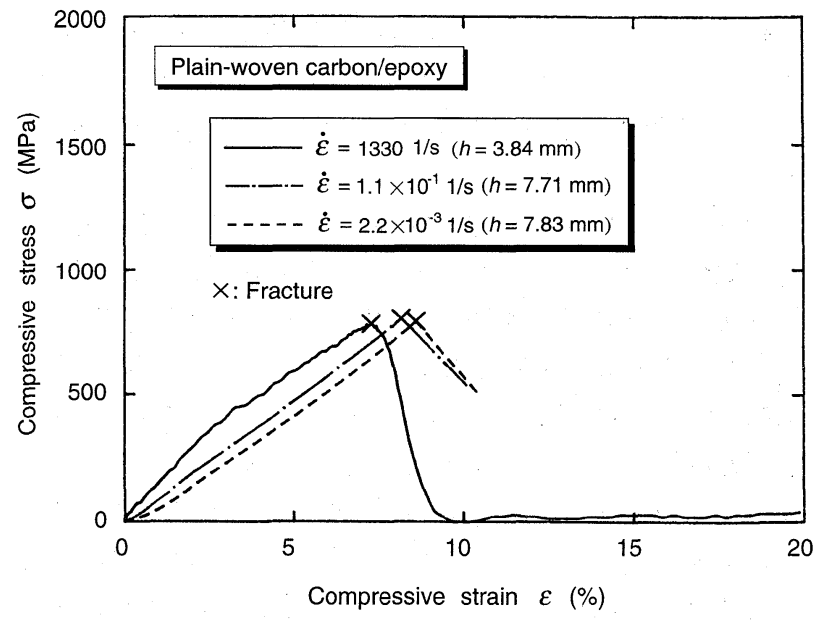

Fig. 8. Through-thickness compressive stress-strain curves for plain-woven carbon/epoxy laminated composite at different strain rates.

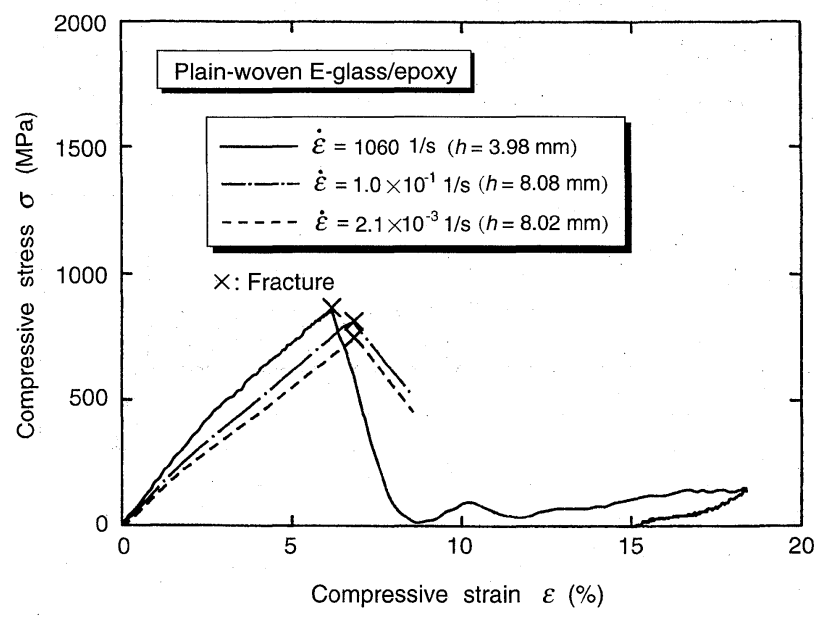

Fig. 9. Through-thickness compressive stress-strain curves for plain-woven E-galss/epoxy laminated composite at different strain rates. 
ひずみ関係を比較すると, 直交積層 CFRP 材だけが応力 が上昇して極限圧縮強度に達する前に，小さなピークが 見られる。これは巨視的な圧壊に至る前に，局所的に層 間はく離を生じたためと思われる。しかし，衝撃圧縮試 験後の直交積層 CFRP 材の円柱状試験片は界面と繊維方 向に沿って小さく粉砕されており，そのような層間はく 離を直接的には確認することはできなかった，直交積層 CFRP 材は低・中ひずみ速度下では他の 2 種類の積層複 合材よりもはるかに大きい極限圧縮強度，極限圧縮ひず み，吸収エネルギをもつが，高ひずみ速度下では圧縮強 度が著しく低下することに注意する必要がある。このよう な傾向は，同じ積層構造を有する直交積層 CFRP 材の板 厚方向の衝撃圧縮強度について Hosur ほか ${ }^{16)}$ も報告して いる。この直交積層 CFRP 材の極限圧縮強度の低下の原 因は, Table IIに示す静的層間せん断強度から推測され るように, 層間強度（結合力）が相対的に弱いため衝撃 荷重下ではく離損傷が生じ易いことが起因していると思 われる。一方, 平織り GFRP 積層材の極限圧縮強度はひ ずみ速度とともに少し上昇している。この結果も Tay か 15)の GFRP 積層材の板厚方向の圧縮強度のひずみ速度 依存性と同じ傾向を示している.

つぎに, 3 種類の積層複合材について低ひずみ速度 (各試験片 5 個), 中ひずみ速度 (各試験片 4 個), 高ひ ずみ速度（各試験片 4 個）での圧縮応力ーひずみ関係か ら得た割線係数，極限圧縮強度，極限圧縮ひずみ，極限 圧縮ひずみまでの吸収エネルギのそれぞれの平均值を，ひ ずみ速度についてプロットした結果を Fig. 10 ～Fig. 13 に示す. Fig. 10 から全ての積層複合材の割線係数がひ ずみ速度と共に，大きく上昇していることがわかる。こ れは積層複合材のマトリックスであるエポキシ樹脂（熱 硬化性樹脂）に固有の粘弾性特性によるものである。こ れと同種類のエポキシ樹脂の圧縮強度のひずみ速度依存 性については, 円柱状バルク試験片を使用して Tay ほか 15) によりすでに実験的に確認されている。

Fig. 11の極限圧縮強度については, 平織り GFRP 材 だけが正のひずみ速度依存性を示すことに注意すべきで

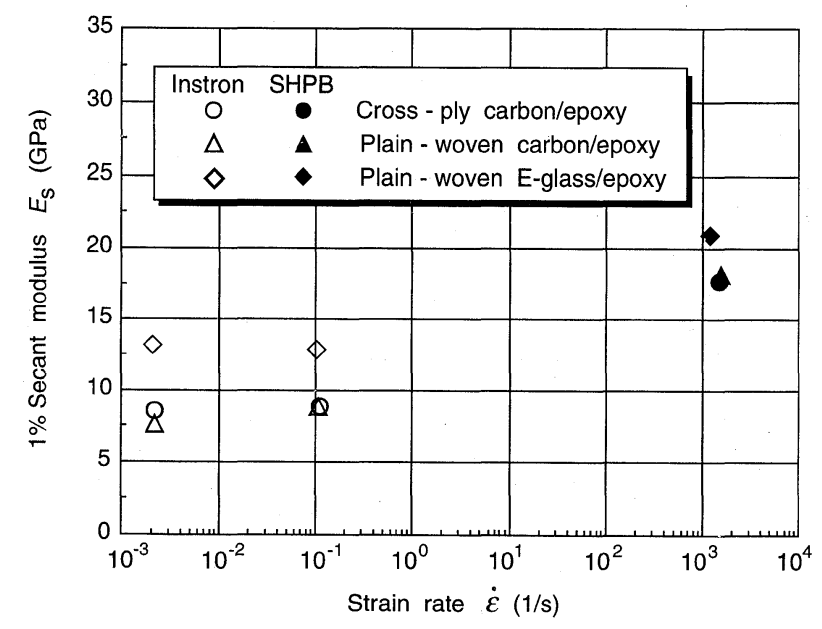

Fig. 10. Effect of strain rate on $1 \%$ secant modulus for three different laminated composites.

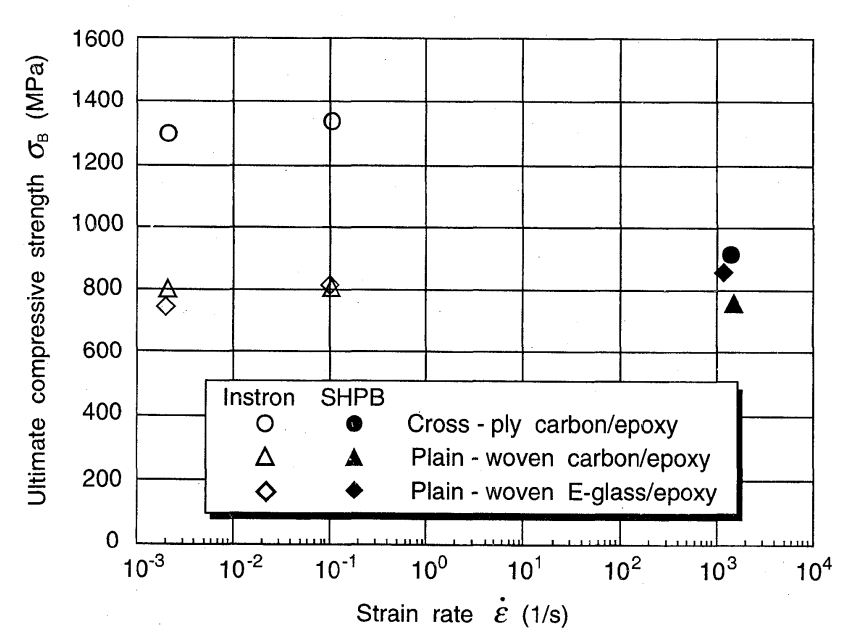

Fig. 11. Effect of strain rate on ultimate compressive strength for three different laminated composites.

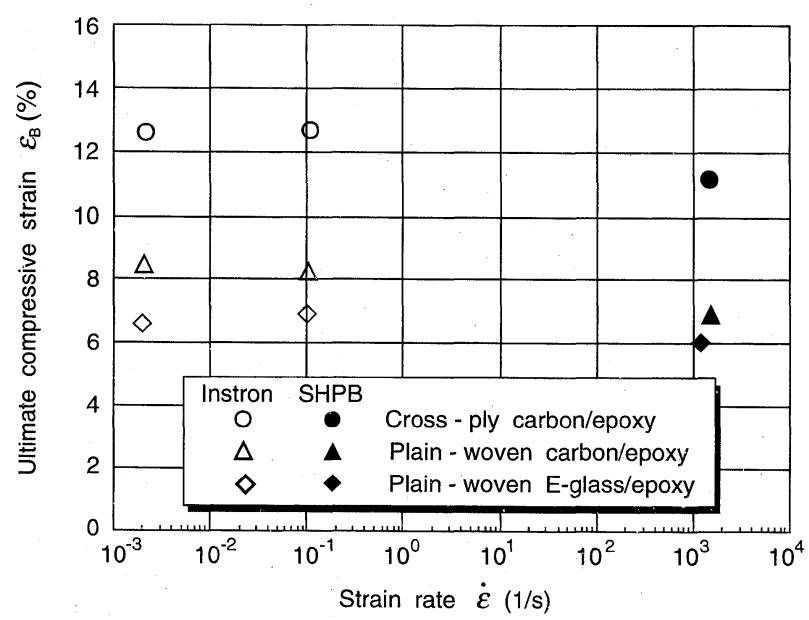

Fig. 12. Effect of strain rate on ultimate compressive strain for three different laminated composites.

ある. Fig. 12 から極限圧縮ひずみについては, 全ての積 層複合材が負のひずみ速度依存性を持つことがわかる. 一方, Fig. 13 における吸収エネルギのひずみ速度依存 性の傾向は, 積層複合材によって異なる. すなわち, 直 交積層 CFRP 材は負のひずみ速度依存性を示すが, 平織

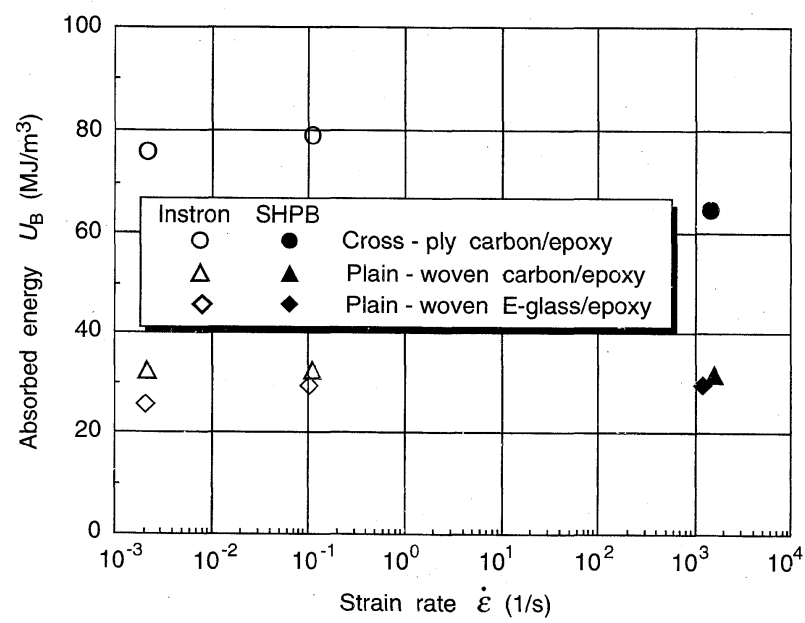

Fig. 13. Effect of strain rate on absorbed energy for three different laminated composites. 
り CFRP 材はほとんどひずみ速度依存性を示さず，平織

り GFRP 材は正のひず久速度依存性を示す。

\section{$4 \cdot 3$ シャルピー衝撃試験}

3 種類の積層複合材から切欠きなしフラットワイズ衝 撃 1 号試験片（長 $80 \mathrm{~mm}$, 幅 $10 \mathrm{~mm}$, 支点間距離 $60 \mathrm{~mm}$ ) (JIS K7061, JIS K7077) を切り出して, シャルピー衝撃 試験機（Zwick 5101：容量 15J）により曲げ吸収エネル ギを測定した結果を Table IVに示す。平織り CFRP 材・ GFRP 材のシャルピー曲げ吸収エネルギの間には大きな 差がみられる。これはTable III に示すように両者の破断 伸び $\varepsilon_{F}$ の差が原因と考えられる。直交積層 CFRP 材につ いては，衝撃負荷時に層間はく離を起こして曲げ破壊し なかったため，吸収エネルギの決定はできなかった。平織 り CFRP 材・GFRP 材のシャルピー曲げ吸収エネルギの 大小関係は Table II に示す静的層間せん断強度のそれと 同じような傾向を示し，板厚方向の極限圧縮ひずみまで の衝撃吸収エネルギの大小関係との相関性は見られない.

\section{5 結言}

3 種類の積層複合材の板厚方向の高ひずみ速度 $(\dot{\varepsilon}=$ $1100 / \mathrm{s} \sim 1500 / \mathrm{s})$ での圧縮応力ーひずみ特性を，標準 型ホプキンソン棒法を使用して評価した．積層複合材の 圧縮特性に及ぼすひずみ速度，プリプレグ形態，強化繊 維材の影響について調べた結果，次のような知見を得た。

(1) 3 種類の積層複合材の $1 \%$ 割線係数は，いずれも ひずみ速度の上昇と共に平均して $1.6 \sim 2.3$ 倍程度増大 する。

（2）直交積層 CFRP 材の極限圧縮強度，極限圧縮ひ ずみ，吸収エネルギは調べたひずみ速度範囲内では，他 の 2 種類の積層複合材のそれらよりも常に大きいが，ひ ずみ速度の上昇と共に平均してそれぞれ $30 \% ， 12 \% ， 15 \%$ 程度も低下する。

(3) 平織り CFRP 材の極限圧縮強度，極限圧縮ひず み，吸収エネルギはひずみ速度の上昇に対して鈍感であ り，平均してそれぞれ $5 \% ， 18 \% ， 2 \%$ 程度减少するにすぎ ない.

（4）平織り GFRP 材の極限圧縮強度と吸収エネルギ

Table IV . Charpy impact energies for three different laminated composites.

\begin{tabular}{c|l|c|c}
\hline & $\begin{array}{l}\text { Cross-ply } \\
\text { carbon/epoxy }\end{array}$ & $\begin{array}{c}\text { Plain - woven } \\
\text { carbon/epoxy }\end{array}$ & $\begin{array}{c}\text { Plain - woven } \\
\text { E-glass/epoxy }\end{array}$ \\
\hline $\begin{array}{c}\text { Charpy impact } \\
\text { energy }(\mathrm{J})\end{array}$ & Not available & $2.5(5) *$ & $7.5(5)$ \\
\hline
\end{tabular}

\footnotetext{
* Figures in parentheses indicate the number of test specimens
}

は，ひずみ速度の上昇と共に平均してそれぞれ $15 \% ， 16 \%$ 程度上昇するが，極限圧縮ひずみは逆に $9 \%$ 程度減少 する。

（5） 3 種類の積層複合材の極限圧縮ひずみまでの衝撃 吸収エネルギの大小関係と，フラットワイズ衝撃試験片 のシャルピー曲げ吸収エネルギのそれとの間には特に相 関性は認められない。

\section{参 考 文 献}

1) "ASTM Standards and Literature References for Composite Materials", 2nd Ed. (1990) ASTM, Philadelphia.

2 ）“JIS ハンドブックープラスチックス”（1999）日本規格協会.

$3)$ R. L. Sierakowski, G. E. Nevill, Jr., C.A. Ross and E. R. Jones, J. Comp. Mater., 5, 362 (1971).

4 ) L. J. Griffiths and D. J. Martin, J. Phys. D, Appl. Phys., 7, 2329 (1974).

5) J. Harding, Composites, 24, 323 (1993).

$6)$ J. Yuan, N. Takeda, D.-Y. Song and A. M. Waas, Mater. Sci. Res. Int., 5, 202 (1999)

7 ) E. Woldesenbet and J. R. Vinson, AIAA, J., 37, 1102 (1999).

8 ) J. R. Vinson and E. Woldesenbet, J. Comp. Mater., 35, 509 (2001).

9 ) J. Harding and L. M. Welsh, J. Mater. Sci., 18, 1810 (1983).

10) G. H. Staab and A. Gilat, J. Comp. Mater., 29, 1308 (1995).

11) J. Rodriguez, I. S. Chocron, M. A. Martinez and V. SanchezGalvez, Composites : Part B, 27B, 147 (1996).

12) S. M. Werner and C. K. H. Dharan, J. Comp. Mater., 20, 365 (1986).

13) J. Harding and Y. L. Li, Comp. Sci. and Technol., 45, 161 (1992).

14) L. Dong and J. Harding, Composites, 25, 129 (1994).

15) T. E. Tay, H. G. Ang and V. P. W. Shim, Comp. Struct., 33, 201 (1995).

16) M. V. Hosur, J. Alexander, U. K. Vaidya and S. Jeelani, Comp. Struct., 52, 405 (2001)

17) H. Kolsky, Proc. Phys. Soc. London, B62, 676 (1949).

18) E. D. H. Davies and S.C. Hunter, J. Mech. Phys. Solids, 11, 155 (1963).

19) K. F. Graff, "Wave Motion in Elastic Solids", Chap.2 (1975) Clarendon Press, Oxford.

20) ASTM E9-89a, “Annual Book of ASTM Standards", p.101 (1995) ASTM, Philadelphia.

21）福井伸二, 工藤英明, 吉田清太, 阿部邦雄, 東京大学理 工学研究所報告, 8, 135 (1954). 